\title{
Reducing the number of microorganisms and organic carbon by implementation of APS (Advanced Ponds System) in the wastewater of dairy goat with added liquid probiotics
}

\author{
Rendi Fathoni Hadi *, Bayu Setya Hertanto, Ari Kusuma Wati \\ Department of Animal Science, Faculty of Agricultural, Universitas Sebelas Maret, Surakarta, 57126 \\ *Correspondence: rendi_fathoni@staff.uns.ac.id \\ Received: December 10 ${ }^{\text {th }}, 2019$; Accepted: October 19 ${ }^{\text {th }}, 2020$; Published online: November $26^{\text {th }}, 2020$
}

\begin{abstract}
Abstrak
Tujuan: Kegiatan kelompok kambing perah pada umumnya belum memperhatikan pengolahan limbah ternak yang berasal dari kegiatan pemeliharaan. Misalnya, seperti kandang pembersih limbah cair dan peternakan, kotoran dan urin, dan aktivitas memerah susu. Limbah peternakan kambing perah jika tidak dikelola dengan baik dapat berdampak negatif pada kualitas sumber air bawah tanah dan air permukaan, dan lingkungan sekitarnya. Penerapan sistem Advanced Ponds System (APS) dengan kolam Algae Settling Ponds ukuran $3 \mathrm{~m}$ x 1,5 m x 1,5 m dengan takaran $50 \mathrm{ml} / \mathrm{m}^{3}$ cairan probiotik sehingga diperlukan sebanyak $337,5 \mathrm{ml}$. Penelitian ini bertujuan untuk mengevaluasi jumlah mikroorganisme dan sifat fisik dan kimia air limbah.

Metode: Variabel yang diamati adalah kandungan mikroorganisme (Escherichia coli dan Salmonella $s p$.) dan karakteristik fisik/kimia ( $\mathrm{N}$ total, bahan organik, suhu, $\mathrm{pH}$, karbon organik, rasio $\mathrm{C} / \mathrm{N}$ ) air limbah peternakan kambing perah pada sistem APS pada bagian Algae Settling Ponds. Data dianalisis dengan analisis uji-t sampel independen.

Hasil: Hasil penelitian menunjukkan bahwa penambahan probiotik cair tidak berpengaruh signifikan terhadap suhu, $\mathrm{pH}$, dan rasio $\mathrm{C} / \mathrm{N}$, tetapi mempengaruhi karbon organik, E. coli dan Salmonella sp. $(\mathrm{P}<0,05)$.

Kesimpulan: Berdasarkan data di atas dapat disimpulkan bahwa penambahan probiotik cair melalui penerapan Advanced Ponds System pada bagian Algae Settling Ponds dapat dijadikan solusi untuk mempercepat peningkatan kualitas air limbah peternakan kambing perah.
\end{abstract}

Kata Kunci: Advanced Ponds System; Kambing Perah; Probiotik; Air limbah

Abstract

Objective: The activities of the dairy goat group, in general, have not paid attention to the processing of livestock waste that comes from maintenance activities. For example, liquid waste from cleaning cages and livestock baths, dirt, urine, and milking activities. Dairy goat farm waste, if not appropriately managed can have a negative impact on the quality of underground water sources, surface water, and the surrounding environment. Application of the Advanced Ponds System (APS) system with at part of Algae Settling Ponds pool size of $3 \mathrm{~m} \times 1.5 \mathrm{~m} \times 1.5 \mathrm{~m}$ with a dose of $50 \mathrm{ml} / \mathrm{m}^{3}$ of probiotic liquid so that $337.5 \mathrm{ml}$ was needed. This study aimed to improve the wastewater based 
on microbiological and psycochemical characteristics by treatment of advanced pond system with probiotic in dairy goat farm.

Methods: The variables observed were the content of microorganisms (Escherichia coli and Salmonella $s p$.) and physicochemical characteristics (Total N, Organic matter, temperature, $\mathrm{pH}$, organic carbon, $\mathrm{C} / \mathrm{N}$ ratio) of dairy goat farm wastewater in the APS system at part of Algae Settling Ponds. Data were analyzed by independent samples t-test analysis.

Results: The results showed that the addition of liquid probiotic had no significant effect on temperature, $\mathrm{pH}$, and $\mathrm{C} / \mathrm{N}$ ratio, but affected organic carbon, E. coli and Salmonella sp. $(\mathrm{P}<0.05)$.

Conclusions: Based on the research results, it can be concluded the addition of liquid probiotic through the application of the Advanced Ponds System with at part of Algae Settling Ponds can be used as a solution to accelerate the improvement of the quality of dairy goat farm wastewater.

Keywords: Advanced Ponds System; Dairy Goat; Probiotic; Wastewater

\section{INTRODUCTION}

The livestock industry increased significantly globally due to increasing demand for animal products. There are however, growing concerns on the environmental risks, associated with the disposal of untreated livestock wastewater into streams and rivers [1]. With the high content of organic matter in livestock wastewater, most of the livestock industry has difficulty managing this wastewater. this is because there are still many livestock industries that dispose of waste water carelessly, causing environmental damage. In addition, climatic factors also affect the composition of livestock wastewater because in dry areas, livestock waste water has a smaller volume with a very high volume concentration than in areas with high rainfall [2].

As understanding of pond operating mechanisms has improved, different types of ponds have been developed to meet specific conditions. Ponds generally requires less energy and lower cost for operation and maintenance compare to other treatment systems [3]. APS (Advanced Ponds System) is specially designed to optimize natural wastewater treatment process and to provide opportunities for resource to recover through capturing energy from biogas, harvesting algal to produce fertilizer and reusing treated effluent [4]. Biological wastewater treatment can be broadly divided into three that is, a biological process with suspended cultures (suspended culture), a biological process with attached culture (attached culture) and process processing with a lagoon or pond system. Biological processes by culture suspended is a processing system with use the activity of micro-organisms to describe the pollutant compounds present in water and microorganisms used are cultured suspended in a pond system [5].

The biological treatment process in an oxidation pond mainly involves an interaction between bacteria, algae and other organisms. It efficiently removes bacteria, biodegradable organics, phosphorous and nitrogen present in the wastewater which is going to be discharged to the receiving streams [6]. Bacterial survival patterns have been extensively described [7, 8]. In different media, bacteria can survive from hours to years. For example, Salmonella sp. can survive for 35 days or 190 days at $22-27^{\circ} \mathrm{C}$ in spotted or solid manure systems, respectively [8], temperature, manure, and protozoan predation are essential factors influencing the survival of Salmonella serovar Typhimurium in soil [9] for 110 days to 968 days in soil, and for 90 days in manure slurries and dirty water [10]. Besides that, light also plays a role in temperature fluctuations and solubility of oxygen in water. Correlation of DO (Dissolved Oxygen) parameters, $\mathrm{pH}$, temperature and light to the ability of algae to absorb nutrients has a large relationship [11].

Bacteria (E. coli) change with time and depend on the type of manure used and its interaction with soil. Escherichia coli can be cultured for a long time from soils with liquid manure additions. E. coli counts were at first peak from soils treated with stable beef cattle manure, then their numbers decreased more 
quickly and the duration of their apparent survival was shorter. The resilience of culturable E. coli was not depend on of their initial numbers in manure [12]. Fecal indicator bacteria including total and fecal coliforms have been used in many countries as a monitoring tool for microbiological impairment of water and to predict of the presence of bacterial, viral and protozoan pathogens. These microorganisms are normaly found in mammal's and bird's faecal, their presence in water may indicate fecal pollution and possible association with enteric pathogens [13].

The impact arising from the contamination of animal waste to humans and animals in contact with the waste water is very significant. This can be seen by the high number of pathogenic bacteria contained in the ground water around the livestock sheds [14]. Increased pollution affects the life of aquatic organisms and reduces water quality so that it is incompatible with it demarcation. Several studies have been conducted using algae as a bioremediation technology for wastewater treatment. Algae and bacteria have a mutually beneficial relationship due to the limited $\mathrm{CO}_{2}$ and $\mathrm{O}_{2}$ needed for algae and bacterial respiration $[15,16]$. Therefore, future application liquid probiotic in the Algae Settling Ponds (ASP) can be furthered by investigating the content of microorganisms and physicochemical quality of dairy goat farm wastewater.

\section{MATERIALS AND METHODS}

\section{Sample preparation Algae Settling Ponds}

The waterwaste from dairy goat farm were transferred to the wastewater reservoirs that have been accommodated of the Algae Settling Ponds in the Advanced Ponds System (Figure 1). As much as $300 \mathrm{ml}$ of wastewater was transferred to a bottle and this procedure were replicate 7 times. Then, application of the Advanced Ponds System (APS) system with a Algae Settling Ponds pool size of $3 \mathrm{~m} \times 1.5 \mathrm{~m} \times$ $1.5 \mathrm{~m}$ with a dose of $50 \mathrm{ml} / \mathrm{m}^{3}$ of probiotic liquid so that $337.5 \mathrm{ml}$ was needed. In treatment (P0) liquid probiotic liquid was not given to wastewater, while in treatment (P1) $337.5 \mathrm{ml}$ of liquid probiotic (P1) was added to the waste water reservoir then incubated for 7 days after which the wastewater sample was taken. The nutrient content of liquid probiotics added for the treatment could be seen on the Table 1. A total of $300 \mathrm{ml}$ treated wastewater (P1) was transferred to bottles with 7 replications. Then, it was homogenized and used for microorganism counting and measurement of chemical properties was homogenized to do the count of microorganisms, the physical and chemical properties of wastewater.

The Measurement of organic matter, organic carbon, and nitrogen

Carbon content was measured in the laboratory using Walkley and Black Method

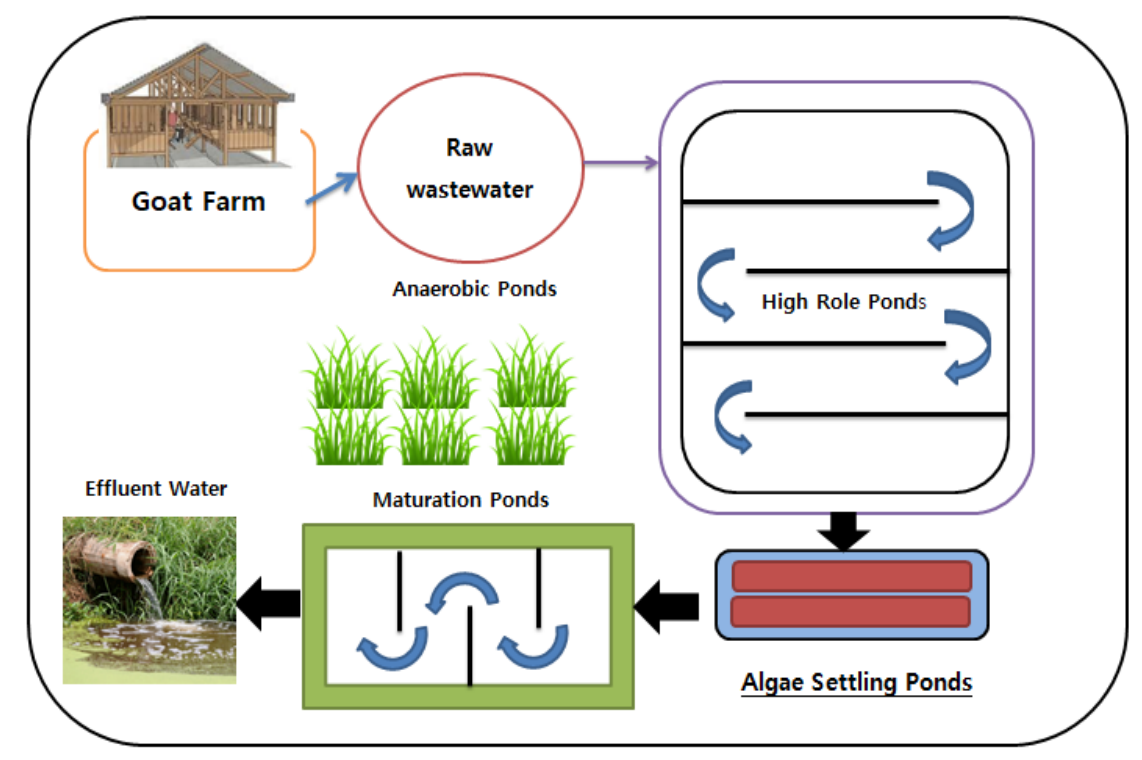

Figure 1. Schematic diagram of a goat dairy-farm with Advanced Pond System (APS) 
and Nitrogen content was analyzed in the laboratory using the Kjeldahl Method [17]. The $\mathrm{C} / \mathrm{N}$ ratio was analyzed by comparing Organic $\mathrm{C}$ values and total $\mathrm{N}$ levels.

\section{Measurement of $\mathrm{pH}$ and temperature value}

$\mathrm{pH}$ and temperature were measured using digital $\mathrm{pH}$ meter and digital thermometer (Omron MC-341).

\section{E. coli counts}

Escherichia coli was identified using Lactose broth medium in which positive result were indicated through formation of gas on the medium. The number of $E$. Coli on lactose media then calculated based on the Most Probable Number (MPN) Table/ml from three tubes isolate [18].

\section{Salmonella sp. counts}

The colony of Salmonella sp. were counted using Salmonella Shigella Agar (SSA) according to [19].

\section{Data analysis}

Data obtained in the current study were analyzed by independent Student's t-test using SPSS 22.

\section{RESULTS AND DISCUSSION}

Table 1. Nutrient content of liquid probiotics

\begin{tabular}{lcc}
\hline \multicolumn{1}{c}{ Parameters } & Result & Unit \\
\hline Lactobasilus $s p$. & $3.3 \times 10^{7}$ & Colony/gram \\
Cellulolytic bacteria & $2.3 \times 10^{8}$ & Colony/gram \\
Proteolytic bacteria & $4.6 \times 10^{6}$ & Colony/gram \\
Yeast & $3.9 \times 10^{7}$ & Colony/gram \\
$\mathrm{P}_{2} \mathrm{O}_{3}$ & 0.59 & $\%$ \\
$\mathrm{Calsium}(\mathrm{Ca})$ & 0.08 & $\%$ \\
$\mathrm{pH}$ & 4.55 & - \\
Magnesium $(\mathrm{Mg})$ & 0.15 & $\%$ \\
Protein & 11.025 & $\%$ \\
Fat & 07.465 & $\%$ \\
Organic C & 31.17 & $\%$ \\
Organic matter & 53.74 & $\%$ \\
$\mathrm{~N}$ & 0.52 & $\%$ \\
K2O & 1.26 & $\%$ \\
Magnesium $(\mathrm{Mg})$ & 0.15 & $\%$ \\
C/N Ratio & 59.94 & $\%$ \\
Dry Matter & 41.45 & $\%$ \\
Crude Fiber & 1.903 & $\%$ \\
E. coli & 0.0 & $\%$ \\
\hline
\end{tabular}

The result showed that the addition of liquid probiotics had significant effect ( $\mathrm{P}$ $<0.05$ ) to the total count of Salmonella sp., E. coli and organic C. However, it did not show a significant difference in the other parameters (Table 2).

The addition of liquid probiotics had significant effect to total count of Salmonella sp. and E. coli. It could be due to the decomposition process and competition between bacteria from probiotics and pathogenic bacterials. Lactic acid bacteria (LAB) strains are potentially promising because they generate bactericidal bioactive agents that are able to control the growth of the pathogens. Beneficial effects conferred by Lactobacilli, including inhibition of gram negative and positive pathogenic bacteria described by Maragkoudakis et al [20] and Charlier et al [21]. However, bacterial pathogen survival in the environment depends on many factors [22]. Other viability factors include osmotic potential; water content; humidity; adsorption to or sorption with in particulate media; sunlight; nutrient availability; competition with and predation by indigenous micro-flora; aggregation; and anti-microbial and some toxic substances $[8,22]$. However, there is additional inactivation, such as toxicity from 
Table 2. The number of microorganisms and physicochemical characteristics of dairy goat farm wastewater

\begin{tabular}{lccc}
\hline \multicolumn{1}{c}{ Parameter } & P0 & P1 & $P$ \\
\hline Salmonella sp. $($ colony/g) & $1.1 \pm 0.21 \times 10^{5 \mathrm{a}}$ & $7.5 \pm 0.25 \times 10^{3 \mathrm{~b}}$ & 0.05 \\
E. coli (MPN/100 ml) (with 95\% Confidence Range) & $>1100(420-4000)^{\mathrm{a}}$ & $1100(180-4100)^{\mathrm{b}}$ & 0.05 \\
Total nitrogen (\%) & $0.13 \pm 0.02$ & $0.10 \pm 0.26$ & $\mathrm{~ns}$ \\
Organic Matter (\%) & $2.43 \pm 0.48$ & $1.81 \pm 0.74$ & $\mathrm{~ns}$ \\
Organic C. $(\%)$ & $1.41 \pm 0.25^{\mathrm{a}}$ & $1.05 \pm 0.37 \mathrm{~b}$ & 0.05 \\
C / N ratio & $10.85 \pm 0.59$ & $10.50 \pm 0.89$ & $\mathrm{~ns}$ \\
$\mathrm{pH}$ & $8.04 \pm 0.77$ & $7.95 \pm 1.57$ & $\mathrm{~ns}$ \\
Temperatur $\left({ }^{\circ} \mathrm{C}\right)$ & $28.2 \pm 2.03$ & $28.60 \pm 2.44$ & $\mathrm{~ns}$ \\
\hline
\end{tabular}

Note: $a, b$ different superscript in the same line showed significantly different; P0 $=$ wastewater without probiotic, $\mathrm{P} 1$ = wastewater with probiotic $50 \mathrm{ml} / \mathrm{m}^{3}$

decomposition products, and microbial antagonism and competition [23].

Addition of liquid probiotic showed a difference $(\mathrm{P}<0.05)$ on oganic $\mathrm{C}$ resulted in farm wastewater. This is due to the decomposition of organic matter content in dairy goat farm wastewater in ASP in dairy goat farm wastewater in ASP. Every composted organic materials have has specific characteristics that are useful to support the composting process, especially carbon (C) and nitrogen $(\mathrm{N})$ content, that determine the biological activity of microorganisms [24]. According to Queiroz et al [25], the breakdown of nitrogen in conventional wastewater treatment processes consists of two stages namely nitrification and denitrification. Nitrification process requires oxygen (aerobic conditions), while denitrification requires conditions without oxygen (anaerobes) so that the aeration will inhibit the denitrification process due to nitrogen in the effluent is still high.

There was no difference total nitrogen, organic matter, $\mathrm{C} / \mathrm{N}$ ratio, $\mathrm{pH}$, and temperature of dairy goat farm wastewater from both groups. Anaerobic digestion is a biochemical prosess by anaerobic microorganisms that occurs in the absence of oxygen. The process of anaerobic digestion is appropriate for all wastewater treatment systems given that the solid can be introduced to the system at an acceptable concentration [26]. This is due to microbes found in bioactivator will elaborate compost materials into simpler compounds such as lignin, proteins and other compounds [27]. According Prayitno and Sholeh [28], increasing residence time will increase the effectiveness of nitrogen reduction. Water jasmine plants will increase residence time and increase the effectiveness of nitrogen reduction when used.

Bacterial pathogen survival in the environment depends on many factors, but mainly temperature [23]. The process of microbial decomposition is influenced by several components, namely dissolved oxygen (DO), $\mathrm{pH}$, temperature and light. Aeration treatment (giving air $/ \mathrm{O}_{2}$ manually) also affects the performance of bacteria to degrade organic matter. The number of microorganisms affects the removal efficiency of COD (chemical oxygen demand) concentration reduction [11]. Manure composition is varies depending on the physiological properties of animals, feed quality, the environment including temperature and humidity [24]. According to Ogunsesin and Aiyelari [29], at this stage, the levels of $\mathrm{C} / \mathrm{N}$ will be lower because the carbon converted to that $\mathrm{CO}_{2}$ and evaporate into the air. The anaerobic biopile environment also encourages pathogen degradation due to alkaline $\mathrm{pH}$ conditions. For example, $\mathrm{pH}$ extremes affect the stability and function of biological macro molecules and the concentration of metabolites and inorganic ions [22]. Other survival factors include offers additional in activation means, such as toxicity from decomposition products, and microbial antagonism and competition [23].

\section{CONCLUSION}

In this study it can be concluded that the addition of probiotic liquid in ASP is effective to reduce organic carbon, Escherichia coli and 
Salmonella sp. Also, the other variables can be considered in improving the quality of wastewater. As conclution, it can be used as a solution to accelerate the improvement of the quality of dairy goat farm wastewater. Furthermore, next research can be carried out by increasing the dose of probiotics so that their effect is more impressive on parameters.

\section{CONFLICT OF INTEREST}

We certify that there is no conflict of interest with any financial organization regarding the material discussed in the manuscript.

\section{ACKNOWLEDGMENT}

The authors gratefully acknowledge to Universitas Sebelas Maret for funding research through the PNPB 2018 Community Service.

\section{REFERENCES}

1. Nik Daud, N. N., and C. S. Anijiofor. 2017. Livestock wastewater generation and farm management: the gap analysis. Acta Hortic. 1152: 265-272. Doi: https://doi. org/10.17660/ActaHortic.2017.1152.36.

2. Harrington, R., and R. McInnes. 2009. Integrated Constructed Wetlands (ICW) for livestock wastewater management. Biores. Tech. 100: 5498-5505. https://doi. org/10.1016/j.biortech.2009.06.007.

3. Corley, C. E. 2011. Principles of design and operations of wastewater treatment pond systems for plant operators, engineers, and managers. EPA, Illinois. p. 1-457.

4. Mambo, P. M., D. K. Westensee, B. M. Zuma, and A. K. Cowan. 2014. The Belmont valley integrated algae pond system in retrospect. Water SA 40: 385-93. Doi: https://doi.org/10.4314/wsa.v40i2.21.

5. Said, N. I. 2006. Daur ulang air limbah (water recycle) ditinjau dari aspek teknologi, lingkungan dan ekonomi. J. Air Indonesia 2: 100-131. Doi: https:// doi.org/10.29122/jai.v2i2.2300.

6. Loganayagi, C., and A. Ramesh. 2014. Mobility of sulfosulfuron and its metabolite aminopyrimidine in soil under laboratory conditions. Res. Rev. J. Ecol. Environ. 2: 47-54.

7. Lemunier, M., C. Francou, S. Rousseaux, S. Houot, P. Dantigny, P. Piveteau, and J. Guzzo. 2005. Long-term survival of pathogenic and sanitation indicator bacteria in experimental biowaste composts. App. Environ. Microbiol. 71(10): 5779-86. Doi: https://doi.org/10.1128/AEM .71.10.5779-5786.2005.

8. Sobsey, M. D., L. A. Khatib, V. R. Hill, E. Alocilja, and S. Pillai. 2006. Pathogens in animal wastes and the impact of waste management practices on the survival, transport and fate. In: J. M. Rice, D. F. Caldwell, F. J. Humenik, Animal Agriculture and the Environment: National Center for Manure and Animal Waste Management White Papers, eds. 2006. ASABE Pub, St. Joseph, Michigan. p. 609-666

9. García, R., J. Bælum, L. Fredslund, P. Santorum, and C. S. Jacobsen. 2010. Influence of temperature and predation on survival of Salmonella Enterica Serovar Typhimurium and expression of Inva in soil and manure-amended soil. App. Environ. Microbiol. 76: 5025-31. Doi: https://doi.org/10.1128/AEM.00628-10.

10. Nicholson, F. A., S. J. Groves, and B. J. Chambers. 2005. Pathogen survival during livestock manure storage and following land application. Biores. Techn. 96: 135-43. Doi: https://doi.org/10.1016/j.biortech.2004 .02 .030 .

11. Putra, A. H., and A. U. Farahdiba. 2018. Performance of algae reactor for nutrient and organic compound removal. Proc. ICST. p. 119-125. Doi: https://dx.doi. org/10.2991/icst-18.2018.26.

12. Unc, A., and M. J. Goss. 2006. Culturable in soil mixed with two types of manure. Soil Science Soc. Amer. J. 70: 763.Doi: https://doi.org/10.2136/sssaj2004.0367.

13. Tyagi, V. K., and A. K. Chopra. 2006. Alternative microbial indicators of faecal pollution: Current perspective. Iranian J. Environ. Health Sci. Eng. 3: 205-16.

14. Penakalapati, G., J. Swarthout, M. J. Delahoy, L. McAliley, B. Wodnik, K. Levy, and M. C. Freeman. 2017. Exposure to animal feces and human health: a 
systematic review and proposed research priorities. Environ. Sci. Tech. 51: 1153711552. Doi: https://doi.org/10.1021/acs.est. $7 \mathrm{~b} 02811$

15. Mahapatra D. M., H. N. Chanakya, T. V. Ramachandra. 2014. Bioremediation and lipid synthesis through mixotrophic algal consortia in municipal wastewater. Biores. Tech. 168: 142-150. Doi: 10.1016/ j.biortech.2014.03.130.

16. Sivakumar, G., J. Xu, R. W. Thompson, Y. Yang, P. Randol-Smith, and P. J. Weathers. 2012. Integrated green algal technology for bioremediation and biofuel. Bioresource Technol. 107: 1-9. Doi: https://doi. org/10.1016/j.biortech.2011.12.091.

17. Dieckow, J., J. Mielniczuk, H. Knicker, C. Bayer, D. P. Dick, and I. Kögel-Knabner. 2007. Comparison of carbon and nitrogen determination methods for samples of a Paleudult subjected to no-till cropping systems. Scientia Agricola 64: 532-540. Doi: https://doi.org/10.1590/S0103-90162007000 500011.

18. Sutton, S. 2010. The most probable number method and its uses in enumeration, qualification, and validation. J. Validation Technol. 16: 35-38. Doi: https://doi.org/ 10.1097/RLI.0b013e318234e75b.

19. Yuliani, N. S., E. Wera, dan P. M. Bulu. 2009. Identifikasi bakteri salmonella sp dan jumlah total kontaminan bakteri coliform pada ikan kembung (Scomber sp.) yang dijual di pasar inpres dan oeba. Jurnal PARTNER. 16: 16-20. Doi: http://dx.doi. org/10.35726/jp.v16i1.49

20. Maragkoudakis P. A., G. Zoumpopoulou, C. Miaris, G. Kalantzopoulos, B. Pot, and T. Tsakalidou. 2006. Probiotic potential of lactobacillus strains isolated from dairy products. Int. Dairy J. 16: 189- 199. Doi: https://doi.org/10.1016/j.idairyj.2005. 02.009 .

21. Charlier C., S. Even, M. Gautier, and Y. le Loir. 2008. Acidification is not involved in the early inhibition of Staphylococcus aureus growth by Lactococcus lactis in milk. Int. Dairy J. 18:197-203. Doi: 10.1016/j.idairyj .2007.03.015
22. Michitsch, R., R. Gordon, R. Jamieson, and G. Stratton. 2017. Bacterial pathogen occurrence and persistence in livestock mortality biopiles. Resources 6(4): 49. https://doi.org/10.3390/resources6040049.

23. Wilkinson, K. G. 2007. The biosecurity of on-farm mortality composting. J. App. Microbiol. 102: 609-18. Doi: https:// doi.org/10.1111/j.1365-2672.2006.03274.x.

24. Widowati, L. R., R. Saraswati, and S. Rochayati. 2011. Nitrogen Cycling and Composting Technologies in Livestock Manure Management. In: Kementerian Pertanian, Data Inventory and Mitigation on Carbon Emission and Nitrogen Cycling from Livestock in Indonesia. Badan Penelitian dan Pengembangan Pertanian. IAARD Press, Jakarta. p. 78-109.

25. Queiroz, L. M., M. V. Aun, D. M. Morita, and P. A. Sobrinho. 2011. Biological nitrogen removal over nitrification/ denitritation using phenol as carbon sources. Brazil J. Chem. Eng. 28: 197-207. Doi: http://dx.doi.org/10.1590/S0104-6632 2011000200004

26. Adekunle, K. F., and J. A. Okolie. 2015. A review of biochemical process of anaerobic digestion. Adv. Biosci. Biotech. 6: 205-212. Doi: http://dx.doi.org/10.4236/abb.2015.63 020 .

27. Sondang, Y., K. Anty, and R. Alfina. 2014. The influence of bioactivator cattle feces against the length of composting and $\mathrm{C} / \mathrm{N}$ ratio from three kind of organic material. Int. J. Adv. Sci. Eng. Inf. Tech. 4: 74-77. Doi: https://doi.org/10.18517/ijaseit.4.4.416.

28. Prayitno, and M. Sholeh. 2014. Pengurangan nitrogen pada limbah cair terolah industri penyamakan kulit menggunakan sistem wetland buatan. Majalah Kulit, Karet, dan Plastik 30: 79-86. Doi: http://dx.doi.org/10.20543/mkkp.v30i 2.129 .

29. Ogunsesin, A., and E. A. Aiyelari. 2017. Effect of swine manure with terminalia Catappa leaves compost and NPK fertilizer on growth and yield of Pepper (Capsicum chinense Jacq.) in Ibadan, Nigeria. Int. J. Sci. Res. Pub. 7: 417-426. 